\section{Focusing neighborhood context and self-rated health in the Pró-Saúde Study}

O foco no contexto da vizinhança na autoavaliação da saúde no Estudo Pró-Saúde

\author{
Analizando el contexto del vecindario y \\ autoevaluación de salud en el Estudio Pró-Saúde
}

Simone M. Santos 1

Guilherme Loureiro Werneck 2

Eduardo Faerstein 2

Claudia S. Lopes 2

Dóra Chor 1 doi: 10.1590/0102-311X00029517

\begin{abstract}
The influence of neighborhood characteristics on self-rated health has been little studied. A multilevel approach using hierarchical models was applied to analyze the relationship between the socioeconomic characteristics in 621 neighborhoods (level 2) in the city of Rio de Janeiro, Brazil, and the selfrated health of 3,054 university employees (level 1) from the baseline of the Pró-Saúde Study. Neighborhoods were created using the SKATER algorithm (Spatial 'K'luster Analysis by Tree Edge Removal) to cluster census tracts according to four indicators and a minimum population of 5,000 people. After adjustment for individual factors (per capita income, schooling, age, sex,

\author{
Correspondence \\ S. M. Santos \\ Departamento de Epidemiologia e Métodos Quantitativos \\ em Saúde, Escola Nacional de Saúde Pública Sergio Arouca, \\ Fundação Oswaldo Cruz. \\ Rua Leopoldo Bulhões 1480, sala 830, Rio de Janeiro, RJ \\ 21041-210, Brasil. \\ smsantos@fiocruz.br \\ 1 Escola Nacional de Saúde Pública Sergio Arouca, Fundação \\ Oswaldo Cruz, Rio de Janeiro, Brasil. \\ 2 Instituto de Medicina Social, Universidade do Estado do Rio de \\ Janeiro, Rio de Janeiro, Brasil.
} ethnicity, health-related behavior and chronic diseases), low level of neighborhood income and higher numbers of members per household were significantly associated with poor self-rated health. Participants living in medium income-level neighborhoods were 34\% more likely to self-rate their health as being poor. Those living in areas with a higher density of members per household were 50\% more likely to present poor self-rated health. Neighborhood context influences self-rated health, beyond the effect of individual factors. Worsening neighborhood socioeconomic conditions affect health adversely, which in turn increasing the chance of poor self-rated health.

Health Status; Socioeconomic Factors; Quality of Life 


\section{Introduction}

Self-rated health is increasingly used as an indicator in epidemiological studies 1 , chiefly due to a negative perception of health that itself consistently predicts functional decline in the elderly 2,3 and adults $4,5,6$. Self-rated health has proven to be a better predictor of adult mortality than objective measurements of health status 7,8 . Several, as yet fully understood, biological, psychological and social factors are considered in the self-rating of health 9,10,11. The relationship between individual characteristics and self-rated health have been the object of studies in Brazil and in international studies $9,12,13,14,15$, but the participation of the contextual characteristics in this relationship has been little explored, especially in Brazil.

Dachs 13 analyzing data from the Brazilian National Household Sample Survey (PNAD 2002) reports that the health status ratings vary with social and economic inequalities across large regions of Brazil: self-rated health values are higher in regions with higher per capita income and percentages of people self-reported as being "white". Apart from the differences associated with income and ethnicity/color, the largest variations relate to gender, age and educational level. Barros et al. ${ }^{14}$, analyzing data from Risk and Protective Factors Surveillance System for Chronic Non-Comunicable Diseases Through Telephone Interview (VIGITEL 2009) found self-rated health was consistently perceived as being worse among women, older individuals, and in individuals that are unemployed and with lower levels of schooling. Women that lived in the North and Northeast had the greatest negative perception of their own health. For men, poor self-rated health were higher in Southeast region in relation to the South region. Over the last two decades, epidemiological and social science studies have increasingly investigated connections between individuals and their living conditions. There is considerable evidence that levels of individual health vary between contexts, such as differing neighborhoods, districts, states and countries 16,17. In addition to their individual characteristics, people's health can be impaired by factors relating to the neighborhood in which they live 18 .

The influence of contextual characteristics on self-rated health has been insufficiently studied 19 . In Brazil, the authors found few published multilevel studies on the subject 16,20,21. Results from these studies were similar to other countries which have found that neighborhood has contextual effects on self-rated health even after adjustment for individual characteristics such as age, ethnicity/color, income, schooling, social class and health status. The many dimensions of neighborhood characteristics that are usually studied can be classified into socioeconomic (income and schooling, economic inequality) 22,23, physical (landscape, pollution, service infrastructure) 24,25 , and psychosocial (social processes that influence the organization of neighborhoods) $26,27,28$. Poor environmental conditions usually have an adverse effect on health, increasing the chance of inhabitants' rating their health as being poor ${ }^{29}$. Even when different socioeconomic indicators are applied, areas that are more deprived, less affluent or with greater income inequalities return higher percentages of individuals with poor self-rated health 29,30,31,32. Physical, environmental characteristics (signs of physical disorder such as graffiti, poor public lighting, waste accumulated in the streets) $33,34,35$ and psycho-social features (social capital) 36,37 , collective efficacy 38 or social cohesion 34 also display an association with self-rated health, although of a lesser magnitude than socioeconomic indicators 39,40 . In England and Scotland, physical, social and political aspects of the environment (such as high levels of unemployment, low access to private transport, poor quality of the physical environment and low levels of political engagement) were all associated with worse self-rated health 38. In Belo Horizonte, Minas Gerais State, poor self-rated health of adults with and without comorbidity were related with perceived problems in the environment 35 .

In a multilevel study of latent variables, Franzini et al. 41 tested a model for structural equations to explain the relationship between economic indicators and multiple dimensions of a neighborhoods physical and social organization, as well as the mechanisms through which these characteristics influence self-rated health. The results showed that socioeconomic factors, such as neighborhood poverty, have direct effects on self-rated health, as well as indirect effects mediated by various psycho-social and physical aspects of the environment, such as social capital, social support, perception of racial discrimination, a climate of fear, and social and physical disorder. These results corroborate the model proposed by Wen et al. 42 , which stresses that the socioeconomic characteristics studied should not only include income levels, but also measures of neighborhood schooling levels, because these indi- 
cators capture different aspects of socioeconomic conditions that may display different impacts on individual self-rated health.

At the same time as specifying factors related to self-rated health, it is also necessary to define the spatial unit of analysis framing the contextual characteristics that are to be studied. The choice of the spatial unit of analysis is critical and can influence the results of the study due to the associations identified between given characteristics and the outcomes on an individual level depend on the scale of the study and the event's prevalence varies from scale to scale. Although the term "neighborhood" is widely used to denominate spatial units of analysis, these can vary from census tracts and their aggregations, postal office areas and districts, through to municipalities and states, all based on political and administrative boundaries ${ }^{43}$. Little attention has been given to the need to choose a definition of "neighborhood" which, in addition to delimiting a spatial unit of analysis, makes it possible to capture the social processes being investigated, this also constitutes a social unit of analysis. In this light, when defining the unit of analysis in studies of relationships between contextual variables and individual health, it is important to consider - in addition to relative internal homogeneity in population and domicile - the political, social and economic dynamics and levels of social interaction among residents.

In order to examine the association between contextual neighborhood characteristics and selfrated health in a population of Brazilian adults in depth, this study analyzed the relationship between individual and contextual indicators and the prevalence of poor self-rated health as reported by participants in the Pró-Saúde Study, a cohort of adult Brazilian civil servants. In particular, it sought to answer two questions: (1) "How much of the variation in self-rated health can be attributed to the neighborhood, before and after adjusting for individual socioeconomic and demographic factors?" and (2) "What effects do neighborhood socioeconomic and demographic characteristics have on selfrated health after adjusting for individual characteristics?".

\section{Methods}

\section{Study population}

The individual data were drawn from the first data collection wave of the Pró-Saúde Study (1999) of a cohort of civil servants at a university in Rio de Janeiro 44. From among the 4,030 participants (91\% of the eligible population), the study analyzed data from 3,054 individuals living in the city of Rio de Janeiro, who answered the questions on self-rated health and whose home addresses were geo-coded.

Each participant's home address was geo-referenced to neighborhood spatial units, using the "SISLOC" address location software at the health information department's geo-processing lab (Laboratório de Informação em Saúde, Instituto de Comunicação e Informação Científica e Tecnológica em Saúde, Fundação Oswaldo Cruz, Rio de Janeiro, Brazil). The participants' places of residence were distributed over 621 of the 794 neighborhoods that make up the municipality.

The neighborhood units used in this study are spatial units, acting as a reference to contextual characteristics, delimited by the SKATER (Spatial 'K'luster Analysis by Tree Edge Removal) 45 clustering algorithm and built up by clustering Rio de Janeiro City's constituent census tracts. Local neighborhood delimitation were described in a previous work according to the methodology developed by Santos et al. 43 . To define this the SKATER method was used based on socioeconomic homogeneity considering four census tract indicators (income, education, persons per household, and percentage of population in the 0-4-year age bracket) and a minimum population of 5,000 people living in each local neighborhood. The purpose of using local neighborhoods was to deal with a spatial unit of aggregated contiguous census tracts that cluster population groups that less socioeconomically heterogeneous than the administratively defined neighborhoods. The process took into account the geographic boundaries between administrative neighborhoods (a political-administrative division larger than a local neighborhood, but smaller than a borough). They display the property of being relatively homogeneous internally, yet heterogeneous as a set, in terms of selected demographic, socioeconomic indicators and in terms of living conditions in the 2000 population census 46 . The boundaries of these neighborhoods accompany Rio de Janeiro's major geographic barriers and borough boundaries. 


\section{Variables analyzed}

\section{- Dependent variable}

The dependent variable was self-rated health, as obtained from responses to the question: "Overall, as compared with people of your age, how do you rate your own health status?”, with the following response options: very good, good, average or poor. For the purposes of these analyses, the answers were re-grouped into two categories: poor (average and poor) and good (good and very good) selfrated health.

\section{- Independent individual variables}

The individual characteristics studied were demographic (sex, age, self-declared ethnicity/color 12,13,14 as categorized by Brazilian Institute of Geography and Statistics, and marital status) and socioeconomic (schooling and per capita family income in minimum wages - MWs), as well as health-related habits and characteristics (physical activity, smoking and body mass index - BMI) and any chronic disease reported (when participants reported having been told by a physician that they suffered from high blood pressure, diabetes mellitus, emphysema, chronic bronchitis or any form of rheumatism).

\section{- Neighborhood context-related independent variables}

The study examined two characteristics of the neighborhood of residence, built up from the 2000 population census data 46: (1) living conditions, as proxy indicated by the average number of dwellers per household; and (2) socioeconomic status, as given by the mean nominal income of those responsible for the household (in MWs: BRL 151.00 or approximately USD 100.00) and categorized in tertiles, and the mean years of schooling completed by those responsible for the households.

\section{Statistical analysis}

Initial analysis was performed through a non-hierarchical logistic regression model for the individual-level variables. At this stage, the variables were analyzed jointly in the model; those that failed to display statistical significance at a 95\% confidence level were not retained in the final model. Later analyses were conducted using hierarchical models in which the 3,054 individuals constituted the first-level units and the 621 neighborhoods, the second-level units. A random-intercepts logistic model was used to analyze the association between variables and the binary outcome (self-rated health dichotomized as poor or good) 47 .

The outcome variability attributed to the neighborhood-context level was assessed by the variance partition coefficient (VPC), obtained from a hierarchical logistic model fitted for only the intercept ("empty" model). Subsequently, neighborhood characteristics were successively entered into the model. Having maintained the contextual variables that displayed statistical significance at a $95 \%$ confidence level, the groups of individual variables defined by demographic, socioeconomic, health-related habit and chronic disease characteristics were gradually incorporated, allowing the parameters estimated for the neighborhood characteristics to be adjusted for individual characteristics. Statistical analyses were performed using the Stata (StataCorp LP, College Station, USA) software package and the map was produced with MapInfo (MapInfo Corp., New York, USA).

\section{Results}

The global prevalence of poor self-rated health was of $17 \%$ (14\% for men and $19 \%$ for women). The highest prevalences of poor self-rated health were seen among non-white female participants aged over 50 with a per capita income of less than $4 \mathrm{MWs}$ and schooling up to primary education completion. The association between self-rated health and marital status varied for men and women: prevalence of poor self-rated health was higher for married men and for separated or widowed women. As 
regards to health-related habits, the highest prevalences of poor self-rated health were seen among participants who did not engage in physical activity, smokers, and those with a BMI of more than $30 \mathrm{~kg} / \mathrm{m}^{2}$. Prevalence of poor self-rated health was also higher among participants who reported chronic disease. In terms of neighborhood income-level categories, the highest prevalences of poor self-rated health were found among residents of neighborhoods in the lower income tertile (Table 1).

The distribution of study participants' domiciles in their respective neighborhoods in Rio de Janeiro City varies widely (1 to 46). The number of participants in each neighborhood was averaging 4.8 individuals per neighborhood.

Table 2 summarizes the estimates for the random components of the various multilevel regression models. Note that in the "empty" model (1), which considers only the degree of variation of the outcome attributed to the distribution of the individual responses (1st level) in the neighborhood spatial units (2nd level), little of the variation (3.5\%) can be attributed to the neighborhood level. The variations in outcome between neighborhoods were not statistically significant in the empty model, not even after incorporating neighborhood characteristics and adjusting for individual characteristics. When mean neighborhood income was incorporated (model 2), the variation attributed to the neighborhood diminished to $0.2 \%$ and, in model 3 , which included the mean number of people per household in the neighborhood, it became negligible. The average number of years' schooling in the neighborhood was not included, since it was not significantly associated with self-rated health.

As both the neighborhood and dimensions of individual characteristics were incorporated into the model, the overall variance in self-rated health could be better explained, especially so when the individual-level variables were included.

Table 3 shows the fixed-effects results with odds ratios (ORs) estimated for each of the variables included in the models and their respective $95 \%$ confidence intervals ( $95 \% \mathrm{CI}$ ).

Model 2 showed that mean neighborhood income level is associated with poor self-rated health. Residents in neighborhoods in both lower and intermediate income tertiles were more likely (96\% and $68 \%$, respectively) to self-rate their health as poor than those living in neighborhoods in the upper income tertile. Model 3 showed that residents in neighborhoods where households averaged more than 3 people were 1.6 times more likely to self-rate their health as poor than those in neighborhoods with fewer members per household.

Model 4, which incorporated the individual demographic characteristics, the odds of poor selfrated health associated with contextual variables decreased slightly, and it should be noted that the association of self-rated health with mean neighborhood income in the lower tertile loses statistical significance. Marital status was not included in this model as it showed no association with the outcome in the univariate analysis. In model 5 , the inclusion of individual socioeconomic characteristics (schooling and income) had a substantial impact on the other estimated coefficients, both for neighborhood characteristics and for individual demographic variables.

Model 6 incorporated chronic disease and the set of health-related habits, so that all groups of individual characteristics were then considered, together with the neighborhood characteristics. Although age categories had displayed no significant association with the outcome, they were retained to adjust the other characteristics. This complete model showed that women were $48 \%$ more likely than men, and black individuals were $35 \%$ more likely than white individuals, to rate their health as poor. People with individual income from 2 to 4 MWs were $35 \%$ less likely to report poor health than those with higher incomes (over 6 MWs). Particularly striking was the much greater likelihood of individuals with incomplete primary education reporting poor health (almost 5 times higher than individuals with a post graduate degree). Similarly, individuals who had completed primary education were $76 \%$ more likely to report poor health. Smoking, lack of physical activity, obesity and the presence of chronic disease were all associated with poor self-rated health.

Although adjusting for individual characteristics weakened the associations between neighborhood characteristics and self-rated health, these were still statistically significant. This finding indicates that the degree to which individuals with similar characteristics are likely to self-rate their health as poor depends on the characteristics of the neighborhood where they live. When all the individual characteristics studied are considered, people living in neighborhoods with a middle income tertile contextual profile are $34 \%$ more likely to self-rate their heath as poor than those living in neighborhoods in the upper income tertile. Likewise, residents of neighborhoods with more numerous house- 
Table 1

Prevalence of poor self-rated health by demographic, socioeconomic, health-related habit and chronic disease characteristics, and by neighborhood socioeconomic characteristics. Pró-Saúde Study, 1999.

\begin{tabular}{|c|c|c|c|c|}
\hline \multirow[t]{2}{*}{ Characteristic } & \multicolumn{2}{|c|}{ Number of participants } & \multicolumn{2}{|c|}{ Prevalence of poor self-rated health } \\
\hline & Male (N) & Female (N) & Male (\%) & Female (\%) \\
\hline Sex & 1,272 & 1,782 & 14.1 & 19.1 \\
\hline \multicolumn{5}{|l|}{ Age (years) } \\
\hline $20-29$ & 199 & 177 & 10.5 & 8.5 \\
\hline $30-39$ & 489 & 671 & 11.0 & 13.4 \\
\hline $40-49$ & 420 & 676 & 15.7 & 20.7 \\
\hline $50-59$ & 131 & 217 & 22.1 & 38.7 \\
\hline Over 60 & 33 & 41 & 27.2 & 29.3 \\
\hline \multicolumn{5}{|l|}{ Ethnicity/Color } \\
\hline White & 730 & 971 & 12.2 & 12.2 \\
\hline Black & 373 & 465 & 18.2 & 26.9 \\
\hline Mixed & 140 & 303 & 12.9 & 28.0 \\
\hline Yellow & 29 & 43 & 13.8 & 30.2 \\
\hline \multicolumn{5}{|l|}{ Marital status } \\
\hline Married & 866 & 982 & 15.7 & 18.4 \\
\hline Separated/Widowed & 135 & 424 & 10.4 & 24.5 \\
\hline Single & 271 & 376 & 10.7 & 14.9 \\
\hline \multicolumn{5}{|l|}{ Per capita income (MW) } \\
\hline Over 6 & 518 & 802 & 12.0 & 12.3 \\
\hline $4-6$ & 283 & 437 & 11.0 & 16.9 \\
\hline $2-4$ & 289 & 359 & 18.0 & 26.5 \\
\hline Under 2 & 182 & 184 & 18.7 & 39.7 \\
\hline \multicolumn{5}{|l|}{ Schooling } \\
\hline Postgraduate & 140 & 326 & 7.1 & 10.4 \\
\hline University & 336 & 555 & 12.2 & 9.0 \\
\hline Secondary complete & 509 & 590 & 12.0 & 20.0 \\
\hline Primary complete & 209 & 226 & 20.6 & 35.0 \\
\hline Primary incomplete & 78 & 85 & 30.8 & 70.6 \\
\hline \multicolumn{5}{|l|}{ Physical activity } \\
\hline Yes & 676 & 795 & 10.7 & 15.4 \\
\hline No & 596 & 987 & 18.0 & 21.4 \\
\hline \multicolumn{5}{|l|}{ Smoking } \\
\hline Never smoked & 770 & 1,153 & 11.0 & 16.7 \\
\hline Former smoker & 233 & 293 & 17.6 & 22.5 \\
\hline Current smoker & 260 & 336 & 20.0 & 24.7 \\
\hline \multicolumn{5}{|l|}{$\mathrm{BMI}\left(\mathrm{kg} / \mathrm{m}^{2}\right)$} \\
\hline Less than 25 & 502 & 945 & 11.0 & 13.2 \\
\hline $25-29.99$ & 551 & 526 & 13.4 & 18.1 \\
\hline 30 or more & 219 & 311 & 22.8 & 39.0 \\
\hline \multicolumn{5}{|l|}{ Chronic disease } \\
\hline No & 886 & 1,147 & 9.1 & 9.2 \\
\hline Yes & 386 & 635 & 25.4 & 37.2 \\
\hline \multicolumn{5}{|c|}{ Neighborhood income level } \\
\hline 3rd tertile (upper) & 382 & 631 & 12.8 & 11.3 \\
\hline 2nd tertile (middle) & 432 & 586 & 14.4 & 21.3 \\
\hline 1st tertile (lower) & 458 & 565 & 14.8 & 25.7 \\
\hline
\end{tabular}

BMI: body masss index; MW: minimum wage. 
Table 2

Variance, standard error estimates, variance partition coefficient and log-likelihoods for different multilevel regression models of prevalence of poor self-rated health. Pró-Saúde Study (1999), Rio de Janeiro, Brazil, neighborhoods (2000).

\begin{tabular}{|c|c|c|c|c|c|}
\hline Models & & Variance & Standard error & $\begin{array}{c}\text { Variance partition } \\
\text { coefficient }\end{array}$ & Log-likelihood \\
\hline “Empty” model 1 & $\begin{array}{l}\text { No variables at neighborhood level and no } \\
\text { individual-level variables }\end{array}$ & 0.1140 & 0.0814 & 0.0346 & $-1,392.31$ \\
\hline Model 2 & Neighborhood mean income & 0.0073 & 0.0724 & 0.0022 & $-1,377.45$ \\
\hline Model 3 & $\begin{array}{l}\text { Neighborhood mean income and mean members } \\
\text { per household }\end{array}$ & 0.0001 & - & - & $-1,360.93$ \\
\hline Model 4 & $\begin{array}{l}\text { Neighborhood mean income and mean members } \\
\text { per household and individual-level demographic } \\
\text { variables * }\end{array}$ & 0.0001 & - & - & $-1,295.59$ \\
\hline Model 5 & $\begin{array}{l}\text { Neighborhood mean income and mean members } \\
\text { per household and individual-level demographic * } \\
\text { and socioeconomic ** variables }\end{array}$ & 0.0001 & - & - & $-1,255.74$ \\
\hline Model 6 & $\begin{array}{l}\text { Mean income and mean members per household, } \\
\text { demographic * and socioeconomic ** variables, } \\
\text { plus individual-level variables for health-related } \\
\text { habits and chronic disease *** }\end{array}$ & 0.0001 & - & - & $-1,151.78$ \\
\hline
\end{tabular}

* Demographic: sex, age, ethnicity/color;

** Socioeconomic: per capita family income and schooling;

*** Health-related habits, physical activity, body mass index, smoking, and chronic disease (subarachnoid hemorrhage, diabetes, chronic lung disease and/or rheumatism).

Table 3

Fixed parameters of multilevel regression models for poor self-rated health. Pró-Saúde Study (1999), Rio de Janeiro, Brazil, neighborhoods (2000).

\begin{tabular}{|c|c|c|c|c|c|c|c|c|c|c|}
\hline \multirow[t]{2}{*}{ Characteristics } & \multicolumn{2}{|c|}{$\begin{array}{c}\text { Model } 2 \\
\text { Neighborhood mean } \\
\text { income only }\end{array}$} & \multicolumn{2}{|c|}{$\begin{array}{c}\text { Model } 3 \\
\text { Neighborhood } \\
\text { mean income and } \\
\text { average members } \\
\text { per household }\end{array}$} & \multicolumn{2}{|c|}{$\begin{array}{c}\text { Model } 4 \\
\text { All neighborhood } \\
\text { variables and } \\
\text { individual } \\
\text { demographic variables }\end{array}$} & \multicolumn{2}{|c|}{$\begin{array}{c}\text { Model } 5 \\
\text { All neighborhood } \\
\text { variables and individual } \\
\text { demographic and } \\
\text { socioeconomic } \\
\text { variables }\end{array}$} & \multicolumn{2}{|c|}{$\begin{array}{c}\text { Model } 6 \\
\text { All neighborhood } \\
\text { variables and } \\
\text { all individual } \\
\text { variables }\end{array}$} \\
\hline & OR & $95 \% \mathrm{Cl}$ & OR & $95 \% \mathrm{Cl}$ & OR & $95 \% \mathrm{Cl}$ & OR & $95 \% \mathrm{Cl}$ & OR & $95 \% \mathrm{Cl}$ \\
\hline \multicolumn{11}{|l|}{ Neighborhood level } \\
\hline \multicolumn{11}{|l|}{ Mean income } \\
\hline 3rd tertile (upper) & 1.00 & & 1.00 & & 1.00 & & 1.00 & & 1.00 & \\
\hline $2^{\text {nd }}$ tertile (middle) & 1.68 * & $1.31-2.15$ & $1.41 *$ & $1.09-1.82$ & 1.37 * & $1.06-1.79$ & 1.26 & $0.96-1.65$ & 1.34 * & $1.01-1.78$ \\
\hline 1st tertile (lower) & 1.96 * & $1.53-2.50$ & 1.33 * & $1.00-1.75$ & 1.22 & $0.91-1.63$ & 1.03 & $0.77-1.39$ & 1.08 & $0.80-1.47$ \\
\hline Members/Household & & & 2.66 * & $1.89-3.76$ & 2.35 * & $1.64-3.35$ & 1.58 * & $1.09-2.30$ & 1.50 * & $1.02-2.23$ \\
\hline \multicolumn{11}{|l|}{ Individual level } \\
\hline \multicolumn{11}{|l|}{ Sex } \\
\hline Male & & & & & 1.00 & & & 1.00 & 1.00 & \\
\hline Female & & & & & 1.44 * & $1.17-1.47$ & 1.64 * & $1.32-2.03$ & 1.48 * & $1.18-1.85$ \\
\hline \multicolumn{11}{|l|}{ Age (years) } \\
\hline $20-29$ & & & & & 1.00 & & 1.00 & & 1.00 & \\
\hline $30-39$ & & & & & 1.23 & $0.83-1.81$ & 1.17 & $0.79-1.74$ & 0.89 & $0.60-1.35$ \\
\hline $40-49$ & & & & & 1.94 * & $1.32-2.85$ & 1.53 * & $1.03-2.27$ & 0.86 & $0.56-1.32$ \\
\hline $50-59$ & & & & & 4.02 * & $2.65-6.12$ & 1.52 * & $1.61-3.93$ & 1.19 & $0.73-1.92$ \\
\hline Over 60 & & & & & 3.40 * & $1.82-6.34$ & 1.70 & $0.87-3.33$ & 0.78 & $0.39-1.59$ \\
\hline
\end{tabular}

(continues) 
Table 3 (continued)

\begin{tabular}{|c|c|c|c|c|c|c|c|c|c|c|}
\hline \multirow[t]{2}{*}{ Characteristics } & \multicolumn{2}{|c|}{$\begin{array}{c}\text { Model } 2 \\
\text { Neighborhood mean } \\
\text { income only }\end{array}$} & \multicolumn{2}{|c|}{$\begin{array}{c}\text { Model } 3 \\
\text { Neighborhood } \\
\text { mean income and } \\
\text { average members } \\
\text { per household }\end{array}$} & \multicolumn{2}{|c|}{$\begin{array}{c}\text { Model } 4 \\
\text { All neighborhood } \\
\text { variables and } \\
\text { individual } \\
\text { demographic variables }\end{array}$} & \multicolumn{2}{|c|}{$\begin{array}{c}\text { Model } 5 \\
\text { All neighborhood } \\
\text { variables and individual } \\
\text { demographic and } \\
\text { socioeconomic } \\
\text { variables }\end{array}$} & \multicolumn{2}{|c|}{$\begin{array}{c}\text { Model } 6 \\
\text { All neighborhood } \\
\text { variables and } \\
\text { all individual } \\
\text { variables }\end{array}$} \\
\hline & OR & $95 \% \mathrm{Cl}$ & OR & $95 \% \mathrm{Cl}$ & OR & $95 \% \mathrm{Cl}$ & OR & $95 \% \mathrm{Cl}$ & OR & $95 \% \mathrm{Cl}$ \\
\hline \multicolumn{11}{|l|}{ Individual level } \\
\hline \multicolumn{11}{|l|}{ Ethnicity/Color } \\
\hline White & & & & & 1.00 & & 1.00 & & 1.00 & \\
\hline Black & & & & & 1.77 * & $1.41-2.23$ & 1.46 * & $1.15-1.85$ & $1.35 *$ & $1.05-1.73$ \\
\hline Mixed & & & & & 1.48 * & $1.12-2.96$ & 1.19 & $0.89-1.60$ & 1.05 & $0.77-1.43$ \\
\hline Yellow & & & & & 1.88 * & $1.05-3.37$ & 1.41 & $0.82-2.76$ & 1.40 & $0.74-2.63$ \\
\hline \multicolumn{11}{|l|}{ Per capita income (MW) } \\
\hline Over 6 & & & & & & & 1.00 & & 1.00 & \\
\hline $4-6$ & & & & & & & 1.05 & $0.79-1.40$ & 1.02 & $0.76-1.37$ \\
\hline $2-4$ & & & & & & & $1.41 *$ & $1.07-1.86$ & $1.35 *$ & $1.01-1.81$ \\
\hline Under 2 & & & & & & & 1.35 & $0.97-1.88$ & 1.30 & $0.92-1.83$ \\
\hline \multicolumn{11}{|l|}{ Schooling } \\
\hline Postgraduate & & & & & & & 1.00 & & 1.00 & \\
\hline University & & & & & & & 1.08 & $0.73-1.59$ & 1.10 & $0.74-1.64$ \\
\hline Secondary complete & & & & & & & 1.50 * & $1.03-2.18$ & 1.34 & $0.91-1.98$ \\
\hline Primary complete & & & & & & & $2.22 *$ & $1.50-2.41$ & $1.76 *$ & $1.13-2.75$ \\
\hline Primary incomplete & & & & & & & $5.46 *$ & $3.30-9.02$ & $4.83 *$ & $2.84-8.20$ \\
\hline \multicolumn{11}{|l|}{ Chronic disease } \\
\hline No & & & & & & & & & 1.00 & \\
\hline Yes & & & & & & & & & $3.46 *$ & $2.76-4.35$ \\
\hline \multicolumn{11}{|l|}{ Physical activity } \\
\hline Yes & & & & & & & & & 1.00 & \\
\hline No & & & & & & & & & $1.60 *$ & $1.29-1.99$ \\
\hline \multicolumn{11}{|l|}{ Smoking } \\
\hline Never smoked & & & & & & & & & 1.00 & \\
\hline Former smoker & & & & & & & & & 1.46 * & $1.11-1.94$ \\
\hline Current smoker & & & & & & & & & $1.65 *$ & $1.27-2.15$ \\
\hline \multicolumn{11}{|l|}{ BMI $\left(\mathrm{kg} / \mathrm{m}^{2}\right)$} \\
\hline Less than 25 & & & & & & & & & 1.00 & \\
\hline $25-29.99$ & & & & & & & & & 0.98 & $0.76-1.27$ \\
\hline 30 or more & & & & & & & & & $2.01 *$ & $1.53-2.64$ \\
\hline
\end{tabular}

95\% Cl: 95\% confidence interval; MW: minimum wage; OR: odds ratio.

* Estimates significant at the $p<0.05$ level.

holds (averaging more than 3 people per domicile) are 50\% more likely to self-rate their health as poor. Note that, after adjusting for average number of members per household in the neighborhood (model 3 ) and individual characteristics (models 4, 5, and 6), residents of neighborhoods in the lower mean income tertile were no more likely to self-rate their health as poor than those in upper average income tertile (reference) neighborhoods.

Table 4 shows the distribution of mean individual income and other neighborhood characteristics by neighborhood income level category. Note that individuals in the study population resident in lower-income neighborhoods had higher mean individual incomes than the mean for their neighborhood. The same did not occur in neighborhoods in the other income categories. The mean incomes of individuals in this study living in medium-income and higher-income neighborhoods were lower than the mean for their neighborhood. 
Distribution of selected variables by neighborhood income level tertiles. Pró-Saúde Study (1999).

\begin{tabular}{|c|c|c|c|c|c|}
\hline \multirow{3}{*}{$\begin{array}{l}\text { Neighborhood income } \\
\text { level }\end{array}$} & \multirow{2}{*}{$\begin{array}{c}\text { Individual } \\
\text { characteristic } \\
\text { Per capita } \\
\text { income in MW }\end{array}$} & \multicolumn{4}{|c|}{ Neighborhood contextual characteristic } \\
\hline & & $\begin{array}{l}\text { Mean nominal } \\
\text { income in } \mathrm{MW}\end{array}$ & $\begin{array}{c}\text { Mean number of } \\
\text { members/household }\end{array}$ & Years' schooling & $\begin{array}{l}\text { Mean } \\
\text { participants per } \\
\text { neighborhood }\end{array}$ \\
\hline & Mean (SD) * & Mean (SD) * & Mean (SD) * & Mean (SD) * & Mean (SD) * \\
\hline 3rd tertile (upper) & $7.4(5.4)$ & $15.3(5.8)$ & $2.9(0.3)$ & $11.6(1.3)$ & $13.2(12.3)$ \\
\hline 2nd tertile (middle) & $5.6(4.5)$ & $7.5(1.2)$ & $3.1(0.3)$ & $9.4(1.7)$ & $9.1(6.8)$ \\
\hline 1st tertile (lower) & $4.2(3.5)$ & $3.8(1.1)$ & $3.3(0.3)$ & $7.4(1.3)$ & $6.7(4.7)$ \\
\hline Total & $5.7(4.7)$ & $8.9(5.9)$ & $3.1(0.3)$ & $9.4(2.3)$ & $9.7(9.0)$ \\
\hline
\end{tabular}

MW: minimum wage; SD: standard deviation.

* Mean and SD in brackets.

\section{Discussion}

This study presents evidence of associations between neighborhood contextual factors and poor selfrated health, even after adjustment for several individual variables. However, the largest portion of variation in self-rated health is found at the individual level, leaving less than $3.5 \%$ to be attributed to the neighborhood context as defined in this study.

Firstly, in models with no individual-level variables, neighborhood income level and number of members per household displayed strong associations with poor self-rated health. As the set of individual characteristics were incorporated, these associations were attenuated. Nonetheless, the associations between neighborhood characteristics and poor self-rated health remained statistically significant, even in the full model that included the individual demographic, socioeconomic, healthrelated habit and chronic disease characteristics.

In the full model, a strong relationship was found between income level and individual schooling, sex and ethnicity, and poor self-rated health. Health-related habits and chronic disease also showed strong association with poor self-rated health. These variables have all been widely described as determinants of self-rated health $12,14,28,35,48$.

The OR estimates showed significant variation in self-rated health related to neighborhood income level and average number of members per household, which cannot be fully explained by compositional individual factors, including individual per capita income, schooling, age, sex, skin color/ethnicity health-related habits and chronic disease.

Review studies 15,49 have identified a number of investigations showing that contextual socioeconomic characteristics play a relatively small role in determining individual self-rated health (unlike other health outcomes, such as those related to violence). In any case, after adjusting for a series of individual characteristics, there is evidence that neighborhood socioeconomic and living conditions have independent effects on self-rated health.

Similar effects, related to the impact of neighborhood affluence and income inequality on the likelihood of individuals' reporting poor health have been found in studies in Chicago, USA 50. One criticism of the validity of results from multilevel studies of health is an alleged trend in the literature towards attributing contextual differences in health to "omitted" compositional individual factors 40 . In this study, several dimensions of individual characteristics were incorporated into the multilevel models so as to permit comprehensive adjustment, including health-related habits and chronic disease, which are often disregarded in studies on the subject 29,51 . In this respect, the possibility should be considered that the analyses performed here may have excessively attenuated the association between neighborhood contextual factors and self-rated health, precisely due to the inclusion of individual health-related habits and chronic disease characteristics, for which no dimension of cor- 
related measurement at the neighborhood level was considered in this study and which probably represent instances of proximal determination, since they are themselves partly determined by social, contextual factors 35,52 .

It is now well established that contextual factors influence the development of individual habits that can be favorable or harmful to health, especially those related to smoking, physical activity and food habits 32 . Higher levels of deprivation and inequality in living conditions are generally associated with unhealthy diets, smoking, being overweight, as well as obesity and physical inactivity ${ }^{41}$. Also certain contextual factors, such as social cohesion and social support, are important mediators of the role of both contextual and individual socioeconomic characteristics in determining health outcomes 19 . There is evidence that neighborhood psycho-social characteristics can mediate the adverse effect of having a chronic disease and attenuate the impact of such conditions on poor self-rated health 53 . A number of studies report significant effects of environmental, social and physical contextual characteristics being perceived as potential mediators in the association mechanism between contextual socioeconomic characteristics and self-rated health $34,37,43,54$.

In this study, the neighborhood context dimensions investigated were restricted to socioeconomic and living condition factors, which may have entailed underestimation of the contextual component of variation in self-rated health, as the physical and psycho-social neighborhood characteristics were not investigated and their contribution to variation in self-rated health may have been attributed to individual health-related habits and chronic disease.

The results showing that neighborhood income level is associated with poor self-rated health although not displaying a rising gradient from the lower to the medium level after adjustment for individual characteristics - are consistent with other studies 55 . Overall, socioeconomically less wellendowed areas have poorer physical and service infrastructures characterized by an under-supply of services (including health services), public transport and leisure areas.

The overall pattern of indicators for the study population, which differs from the general population in their neighborhoods, may have contributed to the fact that their residing in a lower-income level neighborhood did not entail a greater likelihood of poor self-rated health, after adjustment for the other individual and contextual characteristics. We consider that this study population, which lives in low-income neighborhoods, is better placed socio-economically than the overall population of poor areas in Rio de Janeiro City. As it is a population of university workers, all of whom are in employment, wage-earning and benefit from an institutional structure that offers direct or indirect social benefits that are not available to a significant portion of the population of their neighborhoods. In addition, some studies show that low-income populations may hold lower expectations for their health and self-rate their health as better than that of the higher-income population 23,40,41.

Our decision to aggregate health self-ratings into two categories for purposes of analysis facilitates comparison between its results and others already published, but potentially detracts from the informativeness of the original responses obtained on an ordinal scale. However, as compared with the binary outcome model, studies that have analyzed this outcome as an ordinal variable did not show substantial differences in the estimates of coefficients for the independent variables studied 29.

A major limitation of studies (such as ours) that were not specifically designed to assess contextual effects is the small sample size within groups (neighborhoods). In our study, approximately $80 \%$ and $95 \%$ of the neighborhoods had less than 8 and 14 participants, respectively. For binary outcomes with low prevalences $(<10 \%)$, a minimum group size of 50 participants with a minimum of 50 groups is recommended to produce valid estimates 56 . In our study, with around five people per neighborhood and more than 600 neighborhoods, one should not expect substantial bias in the fixed effect estimates, but the estimates of the random intercept are probably overestimated. Therefore, any inference on the variation of the outcome that could be attributed to neighborhood should be made with caution.

Self-rated health measures individuals' perceptions of their own health statuses and can be correlated to personal expectations on health. These expectations can pose problems in developing countries like Brazil, where low-income individuals have a lower tendency to rate their health as poor due to their lower health expectations 12,14 . However, the predictors of individual self-rated health investigated in this study displayed the expected intensity and direction, consistent with evidence already established by other studies $19,28,35,57$. 
The measures of random components in multilevel models provide information on the portion of overall variation in the outcome that can be attributed to place of residence, enabling the statistical estimates to be adjusted by identifying clusters of individuals in the areas 58 . Complementarily, the estimates of fixed components enable relationships to be identified between specific characteristics at both the neighborhood and individual levels and the outcome in the issue 59: self-rated health.

In this study, although the total variance in individual self-rated health was not substantially explained by the neighborhood contextual level, there was a statistically significant association between neighborhood socioeconomic and living condition characteristics and poor self-rated health, even after considering individual characteristics.

\section{Final remarks}

The study of subjective evaluation of health status, a simple measure that is easy to obtain, contributes to analyses of the effects of socioeconomic inequalities at both individual and contextual levels on the health situation. However, it is important to investigate more robust health status indicators, by studying objective health outcomes, morbidity and mortality, in order to advance in understanding how neighborhood socioeconomic structure affects other health outcomes.

This study was conducted in a specific population whose profile is different from the overall population, in that all the participants are employed and a considerable portion of them are in higher individual income brackets and have higher (undergraduate and postgraduate) education levels. Accordingly, the validity of the evidence found is restricted to populations with similar profiles. The participation of neighborhood contextual factors in self-rated health may be underestimated as compared to the city's overall population.

The number of individuals in each neighborhood who participated in the Pró-Saúde Study is not guaranteed to be representative of the population residing in the neighborhood, as sampling was not population-based. There is also major variation in the number of participants in each neighborhood. Despite this constraint, the study constituted substantial progress in terms of the ability to capture the contribution of contextual factors in the health of participants in the Pró-Saúde Study. In a previous study conducted by Tassinari et al. 60 , and which investigated contextual determinants of self-rated oral health, the variability relating to the neighborhood contextual level disappeared when the model was adjusted for individual factors, and the contextual characteristics showed no association with the outcome studied. The administrative neighborhoods (bairros) of Rio de Janeiro City contain very heterogeneous populations that vary widely in number, socioeconomically speaking 43 . This heterogeneity makes it difficult to differentiate contextual factors, because it causes measurements of these factors to regress towards the mean, diluting the impact of the associations that are consequently subsumed. The use of "local" neighborhood - a spatial unit that aggregates populations whose collective profile is more homogeneous both in socioeconomic terms and in population size - as the contextual unit of analysis made it possible to capture the associations between contextual factors and self-rated health.

The contextual effects of socioeconomic factors on health have been studied at various macrolevels. Given the complexity of living conditions in large urban centers, it is fundamentally important to expand investigation of the impacts of contextual factors on health at the intra-municipal level.

The results of this study encourage research into the mechanisms that connect neighborhood socioeconomic characteristics to health. Besides the participation of socioeconomic determinants, indicators of neighborhood physical and psycho-social dimensions should also be investigated. Expanding research into neighborhood contextual characteristics based on integral variables (and not only those derived from population counts) can also contribute to the better capturing of contextual characteristics. It is hoped that in future studies it will be possible to investigate in greater depth how, for example, quality of living environment, resources available in the neighborhood and residents' social organization may affect health outcomes.

Phase 1 of the Pró-Saúde Study was approved in 1999 by the Research Ethics Committee of the Pedro Ernesto Universitary Hospital, Rio de Janeiro State University, Rio de Janeiro, Brazil (registration n. 224/1999). 


\section{Contributors}

S. M. Santos participated in the article's conceptualization and conducted the literature review, structured the database, analyzed and interpreted the compiled data, and wrote the article. G. L. Werneck and D. Chor participated in the article's conceptualization and contributed to the analysis and interpretation of the results and helped write the article. E. Faerstein and C. S. Lopes contributed to the analysis and interpretation of the results and helped write the article

\section{Acknowledgments}

This study was part of the project $A$ Importância da Vizinhança nos Níveis de Saúde Individual: Determinação Ecológica e Individual, e Auto-avaliação de Saúde which was supported by the Brazilian Graduate Studies Coordinating Board (Capes) via a doctoral scholarship.

\section{References}

1. Kawada T. Self-rated health and life prognosis. Arch Med Res 2003; 34:343-7.

2. Idler EL, Benyamini Y. Self-rated health and mortality: a review of twenty-seven community studies. J Health Soc Behav 1997; 38:21-37.

3. French DJ, Browning C, Kendig H, Luscz MA, Saito Y, Sargent-Cox K, et al. A simple measure with complex determinants: investigation of the correlates of self-rated health in older men and women from three continents. BMC Public Health 2012; 12:649.

4. DeSalvo KB, Bloser N, Reynolds K, He J, Muntner P. Mortality prediction with a single general self-rated health question: a metaanalysis. J Gen Intern Med 2006; 21:267-75.

5. Singh-Manoux A, Gheghen A, Martikainen P, Ferrie J, Marmot M, Shipley M. Self-rated health and mortality: short and long-term associations in the Whitehall II Study. Psychosom Med 2007; 69:138-43.

6. Lima-Costa MF, Peixoto SV, Matos DL, Firmo JO, Uchôa E. A influência de respondente substituto na percepção da saúde de idosos: um estudo baseado na Pesquisa Nacional por Amostra de Domicílios $(1998,2003)$ e na coorte de Bambuí, Minas Gerais, Brasil. Cad Saúde Pública 2007; 23:1893-902.

7. Mossey JM, Shapiro E. Self-rated health: a predictor of mortality among the elderly. Am J Public Health 1982; 72:800-8.

8. DeSalvo KB, Muntner P. Discordance between physician and patient self-rated health and allcause mortality. Ochsner J 2011; 11:232-40.

9. Quesnel-Vallée A. Self-rated health: caught in the crossfire of the quest for "true" health. Int J Epidemiol 2007; 36:1161-4.

10. Dowd JB, Zajacova A. Does the predictive power of self-rated health for subsequent mortality risk vary by socioeconomic status in the US? Int J Epidemiol 2007; 36:1214-21.

11. Jylhä M. What is self-rated health and why does it predict mortality? Towards a unified conceptual model. Soc Sci Med 2009; 69:30716.

12. Pavão ALB, Werneck GL, Campos MR. Autoavaliação do estado de saúde e a associação com fatores socioedemográficos, hábitos de vida e morbidade na população: um inquérito nacional. Cad Saúde Pública 2013; 29:723-34.

13. Dachs JNW. Factors determining inequalities in the health condition self-assessment in Brazil: analysis of data of PNAD/1998. Ciênc Saúde Coletiva 2002; 7:641-57.

14. Barros MBA, Zanchetta LM, Moura EC, Malta DC. Auto-avaliação da saúde e fatores associados, Brasil, 2006. Rev Saúde Pública 2009; 43 Suppl 2:27-37.

15. Lima-Costa MF, Firmo JOA, Uchôa E. Differences in self-rated health among older adults according to socioeconomic circumstances: the Bambuí Health and Aging Study. Cad Saúde Pública 2005; 21:830-9. 
16. Santos SM, Chor D, Werneck GL, Coutinho ESF. Association between contextual factors and self-rated health: a systematic review of multilevel studies. Cad Saúde Pública 2007; 23:2533-54.

17. Kawachi I, Berkman LF. Neighborhoods and health. New York: Oxford University Press; 2004.

18. Kawachi I, Subramanian SV. Neighborhood influences on health. J Epidemiol Community Health 2007; 61:3-4.

19. Riva M, Gauvin L, Barnett GA. Toward the next generation of research into small área effects on health: a synthesis of multilevel investigations published since July 1998. J Epidemiol Community Health 2007; 61:853-61.

20. Giatti L, Barreto SM, César CC. Unemployment and self-rated health: neighborhood influence. Soc Sci Med 2010; 71:815-23.

21. Cremonese C, Backes V, Olinto MTA, Diasda-Costa JS, Pattussi MP. Neighborhoodsociodemographic and environmental contexts and self-rated health among Brazilian adults: a multilevel study. Cad Saúde Pública 2010; 26:2368-78.

22. Bobak M, Pikhart H, Rose K, Hertzman C, Marmot M. Socioeconomic factors, material inequalities, and perceived control in selfrated health: cross-sectional data from seven post-communist countries. Soc Sci Med 2000; 51:1343-50.

23. Lucumi DI, Grogan-Kaylor A, Espinosa-Garcia G. Asociación de la posición socioeconómica y la percepción del ambiente con la autopercepción del estado de salud en mujeres de Bogotá, Colombia. Rev Panam Salud Pública 2013; 34:14-20.

24. Sampson RJ, Raudenbush SW. Systematic social observation of public spaces: a new look at disorder in urban neighbourhoods. AJS 1999; 105:603-51.

25. Cohen DA, Mason K, Bedimo A, Scribner R, Basolo V, Farley TA. Neighbourhood physical conditions and health. Am J Public Health 2003; 93:467-71.

26. Omariba DWR. Neighbourhood characteristics, individual attributes and self-rated health among older Canadians. Health Place 2010; 16:986-95

27. Lochner KA, Kawachi I, Brennam RT, Buka SL. Social capital and neighbourhood mortality rates in Chicago. Soc Sci Med 2003; 56:1797-805.

28. Mackenbach JP, Simon JG, Looman CW, Joung IM. Self-assessed health and mortality: could psychosocial factors explain the association? Int J Epidemiol 2002; 31:1162-8.

29. Picket KE, Pearl M. Multilevel analyses of neighbourhood socioeconomic context and health outcomes: a critical review. J Epidemiol Community Health 2001; 55:111-22.

30. Subramanyam MA, Selvaraj S, Kawachi I. Are self-reports of health and morbidities in developing countries misleading? Evidence from India. Soc Sci Med 2009; 68:260-5.
31. Veenstra G. Race, gender, class, and sexual orientation: intersecting axes of inequality and self-rated health in Canada. Int J Equity Health $2011 ; 10: 3$

32. Sharp G, Denney JT, Kimbro RT. Multiple contexts of exposure: activity spaces, residential neighborhoods, and self-rated health. Soc Sci Med 2015; 146:204-13.

33. Stafford M, Cummins S, Macintyre S, Ellaway A, Marmot M. Gender differences in the associations between health and neighborhood environment. Soc Sci Med 2005; 60:1681-92.

34. Cummins S, Stafford M, Macintyre S, Marmot M, Ellaway A. Neighbourhood environment and its associations with self rated health: evidence from Scotland and England. J Epidemiol Community Health 2005; 59:207-13.

35. Meirelles AL, Xavier CC, Andrade ACS, Friche AAL, Proietti FA, Caiaffa WT. Self-rated health in urban adults, perceptions of the physical and social environment, and reported comorbidities: the BH Health Study. Cad Saúde Pública 2015; 31 Suppl:S120-35.

36. Lindén-Boström M, Persson C, Eriksson C. Neighbourhood characteristics, social capital and self-rated health: a population-based survey in Sweden. BMC Public Health 2010; 10:628.

37. Han S, Kim H, Lee H. A multilevel analysis of social capital and selfreported health: evidence from Seoul, South Korea. Int J Equity Health 2012; 11:3.

38. Cagney KA, Browning CR, Wen M. Racial disparities in self-rated health at older ages: what differences does the neighborhood make? J Gerontol B Psychol Sci Soc Sci 2005; 60:S18190.

39. Jun HI, Subramanian SV, Gortmaker S, Kawachi I. A multilevel analysis of women's status and self-rated health in the United States. J Am Med Womens Assoc 2004; 50:172-80.

40. Veenstra G. Location, location, location: contextual and compositional health effects of social capital in British Columbia, Canada. Soc Sci Med 2005; 60:2059-71.

41. Franzini L, Caughy M, Spears W, Esquer MEF. Neighbourhood economic conditions, social processes, and self-rated health in lowincome neighborhoods in Texas: a multilevel latent variables model. Soc Sci Med 2005; 61: 1135-50.

42. Wen M, Browning CR, Cagney KA. Poverty, affluence, and income inequality: neighborhood economic structure and its implications for health. Soc Sci Med 2003; 57:843-60.

43. Santos SM, Chor D, Werneck GL. Demarcation of local neighbourhoods to study relations between contextual factors and health. Int $\mathrm{J}$ Health Geogr 2010; 9:34.

44. Griep RH, Chor D, Faerstein E, Lopes CS. Test-retest reliability of measures of social network in the "Pró-Saúde" Study. Rev Saúde Pública 2003; 37:379-85. 
45. Assunção RM, Neves MC, Câmara G, Costa Freitas C. Efficient regionalization techniques for socio-economic geographical units using minimum spanning trees. Int J Geogr Inf Sci 2006; 20:797-811.

46. Instituto Brasileiro de Geografia e Estatística. Censo demográfico de 2000. Rio de Janeiro: Instituto Brasileiro de Geografia e Estatística; 2000.

47. Bingenheimer JB, Raudenbush SW. Statistical and substantive inferences in public health: issues in the application of multilevel models. Annu Rev Public Health 2004; 25:53-77.

48. Subramanian SV, Huijts T, Avendanoc M. Selfreported health assessments in the 2002 World Health Survey: how do they correlate with education? Bull World Health Organ 2010; 88:131-8.

49. Riva M, Gauvin L, Barnett TA. Toward the next generation of research into small area effects on health: a synthesis of multilevel investigations published since July 1998. J Epidemiol Community Health 2007; 61:853-61.

50. Browning CR, Cagney KA, Wen M. Explaining variation in health status across space and time: implications for racial and ethnic disparities in self-rated health. Soc Sci Med 2003; 57:1221-35.

51. Hou F, Myles J. Neighborhood inequality, neighborhood affluence and population health. Soc Sci Med 2005; 60:1557-69.

52. Canadian Institute for Health Information. State of the evidence review on urban health and healthy weights. http://secure.cihi.ca/cihiweb/dispPage.jsp?cw_page=GR_1929_E (accessed on 07/Mar/2008).

53. Brown AI, Ang A, Pebley R. The relationship between neigborhood characteristics and selfrated health for adults with chronic conditions. Am J Public Health 2007; 97:926-32.
54. Drukker M, van Os J. Mediators of neighbourhood socioeconomic deprivation and quality of life. Soc Psychiatry Psychiatr Epidemiol 2003; 38:698-706.

55. Pei X, Rodriguez E. Provincial income inequality and self-reported health status in China during 1991-7. J Epidemiol Community Health 2006; 60:1065-9.

56. Moineddin R, Matheson FI, Glazier RH. A simulation study of sample size for multilevel logistic regression models. BMC Med Res Methodol 2007; 7:34.

57. Reijneveld SA. Neighborhood socioeconomic context and self reported health and smoking: a secondary analysis of data on seven cities. J Epidemiol Community Health 2002; 56: 935-42.

58. Merlo J, Chaix B, Yang M, Lynch J, Rastam L. A brief conceptual tutorial of multilevel analysis in social epidemiology: linking the statistical concept of clustering to the idea of contextual phenomenon. J Epidemiol Community Health 2005; 59:443-9.

59. Larsen K, Merlo J. Appropriate assessment of neighborhood effects on individual health: integrating random and fixed effects in multilevel logistics regression. Am J Epidemiol 2005; 161:81-8.

60. Tassinari WS, León AP, Werneck GL, Faerstein E, Lopes CS, Chor D, et al. Socioeconomic context and perceived oral health in an adult population in Rio de Janeiro, Brazil: a multilevel analysis. Cad Saúde Pública 2007; 23:127-36. 


\section{Resumo}

Existem relativamente poucos estudos sobre a influência das características de vizinhança sobre a auto-avaliação da saúde. Foi aplicada uma abordagem multinível com modelos hierárquicos para analisar a relação entre as características socioeconômicas de 621 vizinhanças (nível 2) da cidade do Rio de Janeiro, Brasil, e a auto-avaliação da saúde de 3.054 servidores universitários (nível 1) da linha de base do Estudo Pró-Saúde. As vizinhanças foram criadas pela aplicação do algoritmo SKATER (Spatial 'K'luster Analysis by Tree Edge Removal) aos setores censitários, de acordo com quatro indicadores e uma população mínima de 5 mil habitantes. Depois de ajustar para fatores individuais (renda per capita, escolaridade, idade, sexo, raça/cor, comportamentos relacionados à saúde e doenças crônicas), houve uma associação significativa entre renda baixa e número maior de pessoas por domicílio na vizinhança e autoavaliação da saúde "ruim". Os residentes de vizinhanças de renda média apresentaram probabilidade 34\% maior de avaliar a própria saúde como "ruim". Aqueles que viviam em vizinhanças com maior número médio de pessoas por domicílio mostraram uma probabilidade 50\% maior de autoavaliação da saúde "ruim". Para além de fatores individuais, o contexto de vizinhança influencia a autoavaliação da saúde. Piores condições socioeconômicas da vizinhança afetam negativamente a saúde, que por sua vez aumenta as chances de autoavaliação da saúde "ruim".

Nível de Saúde; Fatores Socioeconômicos; Qualidade de Vida

\section{Resumen}

La influencia de las características del vecindario en la salud autoevaluada se ha estudiado escasamente. Se aplicó un análisis multinivel usando modelos jerárquicos para analizar la relación entre las características socioeconómicas en 621 vecindarios (nivel 2), dentro de la ciudad de Río de Janeiro, Brasil, y la salud autoevaluada de 3.054 empleados universitarios (nivel 1), procedentes de la base de referencia del Estudio Pró-Saúde. Se crearon vecindarios con el uso del algoritmo SKATER (Spatial 'K'luster Analysis by Tree Edge Removal), con el fin de agrupar secciones del censo, de acuerdo con cuatro indicadores y una población mínima de 5.000 personas. Tras el ajuste por factores individuales (ingresos per cápita, escolarización, edad, sexo, etnia, comportamiento informado de salud y enfermedades crónicas), el bajo nivel de ingresos en el vecindario y el alto número de miembros por hogar estuvieron significativamente asociados a un escasa salud autoevaluada. Los participantes que vivian en vecindarios con un nivel de ingresos medios tuvieron una probabilidad un 34\% mayor de autoevaluar su salud más bien como mala. Quienes estaban viviendo en vecindarios con una densidad más alta de miembros por vivienda tuvieron una probabilidad de un 50\% mayor de presentar una salud autoevaluada mala. El contexto del vecindario influencia la salud autoevaluada, además del efecto de los factores individuales. Un empeoramiento de las condiciones socioeconómicas en el vecindario afecta adversamente a la salud, que a su vez aumenta la oportunidad de una salud autoevaluada como mala.

Estado de Salus; Factores Socioecocómicos;

Calidad de Vida
Submitted on $21 / \mathrm{Feb} / 2017$

Final versuion resubmitted on 28/Sep/2017

Approved on 31/Oct/2017 